\title{
Hubungan Derajat Merokok Dengan Derajat Eksaserbasi Asma Pada Pasien Asma Perokok Aktif di Bangsal Paru RSUP DR. M. Djamil Padang Tahun 2007 - 2010
}

\author{
Syandrez Prima Putra ${ }^{1}$, Oea Khairsyaf ${ }^{2}$, Julizar $^{3}$
}

Abstrak

Prevalensi asma dan perokok aktif di Indonesia semakin meningkat. Penyakit asma dapat menurunkan kualitas hidup dan menimbulkan kematian terutama pada perokok aktif jika eksaserbasi asma berat terjadi. Penelitian ini bertujuan untuk melihat bagaimana hubungan antara derajat merokok dengan derajat eksaserbasi asma pada pasien asma perokok aktif. Penelitian analitik telah dilakukan dengan menggunakan data deskriptif di Bangsal Paru RSUP Dr. M. Djamil Padang pada bulan Desember 2011 sampai Januari 2013. Data yang dikumpulkan berasal dari catatan rekam medik pasien asma di Bangsal Paru sejumlah 228 orang. Sampel ditetapkan dengan menggunakan teknik total sampling sehingga didapatkan sampel sebanyak lima puluh orang. Untuk melihat hubungan antara derajat merokok dengan derajat eksaserbasi asma digunakan uji korelasi Spearman. Hasil Penelitian menunjukkan 51 dari 228 dari pasien asma (22,4\%) adalah perokok aktif. Secara umum pasien memiliki derajat merokok sedang (41,18\%) dan derajat eksaserbasi asma sedang (78,43\%). Berdasarkan analisis statistik didapatkan nilai $p=0,275(p<0,05)$ yang berarti tidak ada hubungan yang bermakna antara derajat merokok dengan derajat eksaserbasi asma.

Kata kunci: merokok, eksaserbasi, asma

\begin{abstract}
Prevalence of asthma and active smokers in Indonesia has increased. Asthma can reduce quality of life and lead to death especially in active smokers if the severe asthma exacerbation occur. This study aims to look at how the correlation between the degree of smoking by the degree of asthma exacerbation in active smoker patients with asthma. Analytic studies have been conducted using the descriptive data in Pulmonary Ward of RSUP Dr. M. Djamil Padang in December 2011 to January 2013. Data collected from the medical records of patients with asthma history in Pulmonary Ward for 228 people. The samples were appointed by using total sampling technique, so obtained the samples about fifty people. Spearman correlation test was used to examine the relationship between the degree of smoking by the degree of asthma exacerbation. The results of this study showed 51 of 228 of the patients with asthma (22.4\%) were active smokers. In general, patients had a moderate degree of smoking (41.18\%) and moderate degree of asthma exacerbations (78.43\%). The statistical analysis was obtained $p$-value $=0.275(p<0,05)$ which means there is no significant correlation between the degree of smoking by the degree of asthma exacerbation.
\end{abstract}

Keywords: smoking, exacerbation, asthma

Affiliasi penulis : ${ }^{1}$ Mahasiswa FK Unand, ${ }^{2}$ Bagian Paru FK Unand, ${ }^{3}$ Bagian Fisika FK Unand

Korespondensi : Fakultas Kedokteran Universitas Andalas JI.

Perintis Kemerdekaan No.94, Padang. Email: ${ }^{1}$ syandrez@gmail.com

\section{PENDAHULUAN}

Asma merupakan penyakit radang kronis pada saluran pernapasan yang sering terjadi pada masyarakat di berbagai negara di seluruh dunia. Dalam beberapa tahun terakhir, penyakit ini telah menunjukkan peningkatan prevalensi yang cukup signifikan. Menurut data yang dikeluarkan oleh Global Initiative for Asthma (GINA) pada tahun 2011, diperkirakan sebanyak 300 juta manusia menderita asma. ${ }^{1}$ Di Amerika Serikat, berdasarkan data yang dikeluarkan oleh National Center for Health Statistics of the Centers for Disease Control and Prevention (CDC) (2011), selama tahun 2001 sampai dengan tahun 2009, proporsi penderita asma di segala usia meningkat setinggi $12,3 \%{ }^{2}$ Sedangkan di Indonesia, dari data Riset Kesehatan Dasar (Riskesdas) tahun 2007, prevalensi penyakit asma mencapai $4 \%$. ${ }^{3}$ Angka ini jauh di atas prevalensi asma pada tahun 1995 menurut Survei Kesehatan Rumah Tangga (SKRT) yang hanya $1,3 \% .{ }^{4}$ Selain itu, Sumatera Barat sebagai salah satu propinsi di Indonesia mencatat angka prevalensi asma sebesar $3,6 \%$ pada tahun $2007 .^{3}$

Asma merupakan penyakit saluran napas kronis yang dapat bersifat ringan, akan tetapi dapat menetap serta mengganggu aktivitas sehari-hari. Meskipun jarang menimbulkan kematian, penyakit ini sering menimbulkan masalah dalam beraktifitas. Asma dapat menimbulkan gangguan emosi seperti cemas dan depresi, menurunkan produktivitas seseorang akibat tidak masuk kerja atau sekolah, serta dapat menimbulkan kecacatan sehingga menurunkan kualitas hidup. ${ }^{5,6}$ Menurut Imelda, dkk (2007), hubungan antara penurunan kualitas hidup dengan derajat asma seseorang mempunyai korelasi yang positif, bahkan, eksarserbasi asma yang berat dapat mengancam kehidupan. ${ }^{5}$

Eksaserbasi asma (serangan asma atau asma akut) adalah episode peningkatan progresif dari sesak napas, batuk, wheezing, dada terasa berat, atau beberapa kombinasi dari gejala-gejala tersebut. Hal ini ditandai dengan penurunan volume udara ekspirasi yang dapat dinilai dengan pengukuran volume ekspirasi paksa detik pertama (forced expiration volume-1) atau arus puncak ekspirasi (peak expiration 
flow) pada pemeriksaan fungsi paru. Selain itu, derajat eksaserbasi asma dapat ditentukan berdasarkan tingkat keparahan gejala pada saat eksaserbasi asma yang meliputi ringan, sedang, berat, dan terancam gagal napas.

Eksaserabasi asma dapat dipicu oleh berbagai macam faktor pencetus seperti alergen, infeksi, polusi udara, makanan serta paparan asap rokok. ${ }^{1,7}$ Paparan terhadap asap rokok dapat memperburuk gejala asma dan menyebabkan eksaserbasi asma baik pada perokok aktif mapun pasif. ${ }^{8}$ Apabila dibandingkan dengan perokok pasif, perokok aktif memiliki gejala asma yang lebih berat, serangan asma yang lebih sering, dan skor keparahan asma yang lebih tinggi. ${ }^{9}$ Sekitar $25 \%$ dari penderita asma di negara-negara berkembang merupakan perokok aktif. ${ }^{10}$

Terkait dengan hal tersebut, Indonesia merupakan salah satu negara berkembang yang memiliki jumlah perokok aktif yang tinggi. Seperti halnya asma yang mengalami peningkatan, jumlah perokok aktif di Indonesia juga demikian. Berdasarkan data dari Riset Kesehatan Dasar (Riskesdas) oleh Kementrian Kesehatan Republik Indonesia, jumlah perokok aktif di Indonesia meningkat dari $28,2 \%$ pada tahun 2007 menjadi 34,7\% pada tahun 2010. Peningkatan prevalensi ini juga terjadi di Provinsi Sumatera Barat, dimana meningkat dari $30,2 \%$ pada tahun 2007 menjadi $38,4 \%$ pada tahun 2010 . $^{3,11}$ Selain itu, pada tahun 2008, World Health Organization (WHO) telah menetapkan Indonesia sebagai negara terbesar ketiga di dunia sebagai pengguna rokok. ${ }^{12}$

Perokok aktif dapat dibagi menjadi beberapa kelompok berdasarkan berat-ringannya derajat merokok. Perhimpunan Dokter Paru Indonesia membagi tingkatan derajat merokok seseorang menjadi tiga kelompok dengan menggunakan nilai Indeks Brinkman, yakni ringan, sedang dan berat. ${ }^{13}$ Indeks Brinkman merupakan suatu variabel representatif untuk menggambarkan berat ringannya merokok seseorang secara kuantitatif. ${ }^{14}$ Nilai dari indeks tersebut dihitung berdasarkan jumlah batang rokok yang dihisap sehari dikali dengan lama merokok dalam tahun. ${ }^{15}$

Berdasarkan penjelasan di atas, prevalensi asma dan jumlah perokok aktif di Indonesia samasama mengalami peningkatan. Akan tetapi penelitian tentang hubungan antara derajat beratnya merokok dengan derajat eksaserbasi asma belum banyak dilakukan termasuk di wilayah Sumatera Barat. Rumah Sakit Umum Pusat (RSUP) dr. M. Djamil Padang adalah sebagai salah satu rumah sakit rujukan untuk daerah Sumatera Barat dan beberapa daerah di Sumatera bagian tengah, termasuk sebagai tujuan rujukan pasien penyakit asma. Prevalensi asma di Bangsal Paru RSUP dr. M. Djamil Padang cukup tinggi (rata-rata 40 pasien per tahun). Hasil observasi sementara dari rekam medik yang ada, sekitar $20 \%$ penderita asma tersebut adalah perokok aktif. Disamping itu juga belum ditemukan penelitian yang menghubungkan derajat merokok dengan derajat eksaserbasi asma di rumah sakit ini. Berdasarkan hal ini, penulis tertarik untuk meneliti apakah ada hubungan antara derajat merokok dengan derajat eksaserbasi asma ini di Bangsal Paru RSUP dr. M. Djamil Padang.
Penelitian ini dilakukan di Bangsal Paru RSUP Dr. M. Djamil Padang pada bulan Desember 2011 - Januari 2013. Sampel dalam penelitian ini sebanyak 50 orang. Sampel merupakan pasien asma perokok aktif yang memenuhi kriteria inklusi dan tidak memiliki kriteria eksklusi. Pemilihan sampel dilakukan secara total sampling. Instrumen yang digunakan dalam penelitian adalah data rekam medik pasien asma di Bangsal Paru RSUP Dr. M. Djamil Padang pada tahun 2007 2010. Data yang diperoleh diolah dengan menggunakan sistem komputerisasi kemudian dianalisis dengan uji korelasi Spearman dengan tingkat pemaknaan $p<0,05$.

\section{HASIL DAN PEMBAHASAN}

Didapatkan pasien asma sebanyak 228 orang, dengan jumlah pasien asma perokok aktif sebanyak 51 orang (22,4\%). Berpedoman kepada standar Kemenkes RI (2010), ${ }^{11}$ tabel 1 menunjukkan kelompok umur tertinggi adalah 45 - 54 tahun $(25,49 \%)$ dengan jenis kelamin yang terbanyak adalah laki-laki $(96,08 \%)$ dan sebagian besar bekerja sebagai pegawai $(45,10 \%)$.

Tabel 2 menunjukkan bahwa kelompok terbanyak adalah pasien asma perokok aktif dengan derajat merokok sedang $(41,18 \%)$. Namun satu dari 51 pasien $(1,96 \%)$ tidak memiliki data derajat merokok yang lengkap, sehingga selanjutnya tidak dimasukkan ke dalam penelitian karena tidak memenuhi kriteria inklusi penelitian, jadi hanya ada 50 sampel yang memenuhi syarat penelitian.

Tabel 3 menunjukkan bahwa sebagian besar pasien asma perokok aktif mengalami eksaserbasi asma derajat sedang (78,43\%).

Tabel 4 memperlihatkan hasil uji korelasi Spearman tidak menunjukkan korelasi yang bermakna antara derajat merokok dengan derajat eksaserbasi asma dengan nilai $p=0,275(p>0,05)$. Kekuatan korelasi sangat lemah dengan nilai $r=0,157(r=0,00$ $-0,199)$, namun korelasi bersifat searah dengan nilai $\mathrm{n}=50 .{ }^{16}$

Berdasarkan hasil penelitian di atas, diperoleh bahwa jumlah pasien asma perokok aktif adalah 51 orang (22,4\%). Angka ini sesuai dengan beberapa hasil penelitian sebelumnya, dimana ratarata penderita asma yang merokok di negara-negara berkembang berkisar antara $20 \%$ sampai $35 \% .{ }^{17-20} \mathrm{Di}$ Indonesia, prevalensi pasien asma perokok aktif mencapai angka $30,24 \% .{ }^{21}$ Jika dilihat dari teori epidemiologi, meskipun merokok diketahui sebagai pencetus eksaserbasi asma, akan tetapi masih banyak masyarakat penderita asma yang tetap merokok dan sama sekali tidak menghindari aktifitas merokok. ${ }^{22,23}$ $\mathrm{Hal}$ ini mungkin disebabkan karena masih rendahnya kesadaran masyarakat tentang bahaya merokok dan minimnya regulasi yang mengatur penggunaan rokok di negara-negara berkembang, sehingga masyarakatnya dapat dengan mudah membeli dan mengonsumsi rokok.

Berdasarkan karakteristiknya, kelompok umur tertinggi pada pasien asma perokok aktif adalah 45 54 tahun $(25,49 \%)$, hal ini sejalan dengan penelitian Kemenkes RI (2010), dimana jumlah perokok aktif pada kelompok umur tersebut adalah yang tertinggi di Indonesia. ${ }^{11} \mathrm{Hal}$ ini mungkin disebabkan karena di usia tersebut mulai terjadi penurunan produktifitas kerja sehingga seseorang lebih banyak memiliki waktu luang untuk menghisap rokok. 
Menurut jenis kelamin, hampir seluruh pasien adalah laki-laki (96,08\%). Hal ini sesuai dengan beberapa penelitian yang menempatkan laki-laki sebagai pengguna rokok terbesar di Indonesia. ${ }^{11,12} \mathrm{Hal}$ ini mungkin disebabkan karena laki-laki pada umumnya sudah mulai merokok di usia muda akibat pengaruh lingkungan dan pergaulan serta dampak dari ketergantungan terhadap rokok sampai usia dewasa.

Menurut pekerjaan, pegawai merupakan yang terbanyak di antara pekerjaan pasien asma perokok aktif $(45,10 \%)$. Hal ini berbeda dengan hasil Riset Kesehatan Dasar 2010 yang mendapatkan angka yang lebih tinggi pada kelompok petani/buruh/nelayan. ${ }^{11}$ Perbedaan ini disebabkan karena jumlah sampel penelitian dari Kemenkes $\mathrm{RI}$ jauh lebih besar dibandingkan penelitian ini, sehingga di dapatkan data yang lebih heterogen.

Tabel 2 memperlihatkan derajat merokok, sebagian besar pasien asma perokok aktif memiliki derajat merokok sedang $(41,18 \%)$ dan ringan $(33,33 \%)$. Hal ini sedikit berbeda dengan penelitian sebelumnya yang menunjukkan bahwa pasien asma perokok aktif di Indonesia merokok sebanyak $11-20$ batang per hari $(60,63 \%)$ dan lebih dari 20 tahun $(44,4 \%)$, dengan demikian pasien asma perokok aktif di Indonesia pada umumnya memiliki Indeks Brinkman di atas angka 220 dengan kategori derajat merokok sedang hingga berat. ${ }^{21}$ Bika jumlah perokok sedang dan berat pada penelitian ini digabungkan, maka jumlahnya melebihi perokok ringan. Tingginya jumlah perokok berderajat sedang dan berat dapat disebabkan oleh banyaknya batang rokok yang dihisap setiap hari, selain itu sebagian besar usia pasien sudah melebihi 45 tahun sehingga usia merokok pasien sudah lebih lama.

Berdasarkan derajat eksaserbasi asma yang diderita, diperoleh bahwa mayoritas pasien asma perokok aktif mengalami eksaserbasi derajat sedang $(78,43 \%)$ hingga berat $(17,65 \%)$, sedangkan eksaserbasi derajat ringan sangat sedikit $(3,92 \%)$. Hal ini disebabkan karena merokok dapat meningkatan derajat hiperresponsifitas bronkus, menyebabkan bronkokonstriksi akut dan dapat menurunkan FEV secara langsung. ${ }^{24,25}$ Penelitian Jang, et al (2010) juga menemukan bahwa perokok aktif akan memperlihatkan gejala asma yang lebih berat, kebutuhan pertolongan medis yang lebih besar dan status kesehatan yang lebih rendah dibandingkan bukan perokok aktif. ${ }^{24}$ Dengan demikian, dapat diansumsikan bahwa pasien asma perokok aktif dapat menderita eksaserbasi asma yang lebih berat dibandingkan pasien asma bukan perokok.

Hubungan antara derajat merokok dengan derajat eksaserbasi asma pada pasien asma perokok aktif diuji dengan uji korelasi Spearman (Tabel 4). Hasil penelitian menunjukkan bahwa tidak terdapat korelasi yang bermakna antara kedua variabel. Kekuatan korelasi antara kedua variabel adalah sangat lemah, hal ini dapat disebabkan karena pada pasien asma perokok aktif didapatkan penyakit lain yang menyertai penyakit asma, sehingga hal tersebut dapat mempengaruhi derajat eksaserbasi asma. ${ }^{15}$ Korelasi ini memiliki arah yang positif, dimana semakin berat derajat merokok, maka semakin berat derajat eksaserbasi asma yang dialami oleh pasien. Hal ini menunjukkan adanya pengaruh derajat merokok terhadap derajat eksaserbasi asma, walaupun kekuatannya sangat lemah dan tidak bermakna.
Secara teoritis, eksaserbasi asma dipengaruhi oleh faktor pencetus seperti alergen, polusi udara, infeksi, makanan, serta paparan asap rokok. $^{1,7}$ Namun, paparan alergen dan infeksi di saluran pernapasan adalah faktor yang terpenting dalam eksaserbasi asma dan dapat menimbulkan efek serangan yang lebih lama. ${ }^{1}$ Meskipun merokok dapat menyebabkan bronkokonstriksi akut, akan tetapi tidak semua paparan asap rokok berperan sebagai iritan pada pasien asma. ${ }^{24} \mathrm{Di}$ sisi lain, risiko eksaserbasi asma akan dapat berkurang apabila pasien mendapatkan kontrol klinis yang baik, walaupun pada pasien asma yang merokok cenderung lebih sulit.

Dari hasil penelitian, didapatkan sebagian besar $(68,63 \%)$ pasien asma perokok aktif mengalami penyakit penyerta lainnya. Penyakit terbanyak yang diderita adalah bronkhitis akut $(29,41 \%)$, community acquired pneumonia (CAP) $(21,57 \%)$, dan tuberkulosis paru $(11,76 \%)$. Ketiga penyakit ini pada umumnya disebabkan oleh infeksi mikroorganisme pada saluran pernapasan, baik virus maupun bakteri. ${ }^{26-28}$ Jika dihubungkan dengan data yang dilaporkan GINA (2011), maka ketiga penyakit penyerta di atas diasumsikan dapat menjadi penyebab utama eksaserbasi asma dan dapat pula mempengaruhi derajat eksaserbasi asma. ${ }^{1}$

\section{KESIMPULAN}

1. Lima puluh satu dari 228 pasien asma adalah perokok aktif, dengan kelompok tertinggi di usia 45 - 54 tahun, berjenis kelamin laki-laki, dan bekerja sebagai pegawai.

2. Sebagian besar pasien asma perokok aktif memiliki derajat merokok sedang.

3. Sebagian besar pasien asma perokok aktif memiliki derajat eksaserbasi asma sedang.

4. Tidak ada hubungan bermakna antara derajat merokok dengan derajat eksaserbasi asma pada pasien asma perokok aktif. 
Tabel 1. Distribusi pasien asma perokok aktif yang berobat di Bangsal Paru RSUP dr. M. Djamil Padang pada tahun 2007 sampai 2010 menurut karakteristik

\begin{tabular}{|c|c|c|}
\hline \multirow{2}{*}{ Karakteristik } & \multicolumn{2}{|c|}{$\begin{array}{l}\text { Pasien Asma } \\
\text { Perokok Aktif }\end{array}$} \\
\hline & $\begin{array}{l}\text { Jumlah } \\
\text { (orang) }\end{array}$ & $\begin{array}{c}\text { Persentase } \\
(\%)\end{array}$ \\
\hline \multicolumn{3}{|l|}{$\begin{array}{l}\text { Kelompok Umur } \\
\text { (Tahun) }\end{array}$} \\
\hline $15-24$ & 5 & 9,80 \\
\hline $25-34$ & 6 & 11,76 \\
\hline $35-44$ & 8 & 15,69 \\
\hline $45-54$ & 13 & 25,49 \\
\hline $55-64$ & 9 & 17,65 \\
\hline $65-74$ & 6 & 11,76 \\
\hline$\geq 75$ & 4 & 7,84 \\
\hline Total & 51 & 100 \\
\hline \multicolumn{3}{|l|}{ Jenis Kelamin } \\
\hline Laki-laki & 49 & 96,08 \\
\hline Perempuan & 2 & 3,92 \\
\hline Total & 51 & 100 \\
\hline \multicolumn{3}{|l|}{ Pekerjaan } \\
\hline $\begin{array}{l}\text { Tidak } \\
\text { Bekerja }\end{array}$ & 1 & 1,96 \\
\hline Sekolah & 1 & 1,96 \\
\hline Pegawai & 23 & 45,10 \\
\hline Wiraswasta & 16 & 31,37 \\
\hline $\begin{array}{l}\text { Petani/ } \\
\text { Nelayan/ } \\
\text { Buruh }\end{array}$ & 9 & 17,65 \\
\hline Lainnya & 1 & 1,96 \\
\hline Total & 51 & 100 \\
\hline
\end{tabular}

Tabel 2. Distribusi derajat merokok pada pasien asma perokok aktif yang berobat di Bangsal Paru RSUP dr. M. Djamil Padang pada tahun 2007 sampai 2010

\begin{tabular}{ccc}
\hline \multirow{2}{*}{$\begin{array}{c}\text { Derajat } \\
\text { Merokok }\end{array}$} & \multicolumn{2}{c}{$\begin{array}{c}\text { Pasien Asma Perokok } \\
\text { Aktif }\end{array}$} \\
\cline { 2 - 3 } & $\begin{array}{c}\text { Jumlah } \\
\text { (orang) }\end{array}$ & $\begin{array}{c}\text { Persentase } \\
\text { (\%) }\end{array}$ \\
\hline Ringan & 17 & 33,33 \\
Sedang & 21 & 41,18 \\
Berat & 12 & 23,53 \\
$\begin{array}{c}\text { Tidak } \\
\text { tercatat di } \\
\text { Rekam } \\
\text { Medik }\end{array}$ & 1 & 1,96 \\
\hline Total & $\mathbf{5 1}$ & $\mathbf{1 0 0 \%}$ \\
\hline
\end{tabular}

Tabel 3. Distribusi derajat eksaserbasi asma pada pasien asma perokok aktif di Bangsal Paru RSUP Dr. M. Djamil Padang pada tahun 2007 sampai 2010

\begin{tabular}{ccc}
\hline \multirow{2}{*}{$\begin{array}{c}\text { Derajat } \\
\text { Eksaserbasi Asma }\end{array}$} & \multicolumn{2}{c}{$\begin{array}{c}\text { Pasien Asma Perokok } \\
\text { Aktif }\end{array}$} \\
\cline { 2 - 3 } & $\begin{array}{c}\text { Jumlah } \\
\text { (orang) }\end{array}$ & $\begin{array}{c}\text { Persentase } \\
\text { (\%) }\end{array}$ \\
\hline Ringan & 2 & 3,92 \\
Sedang & 40 & 78,43 \\
Berat & 9 & 17,65 \\
$\begin{array}{c}\text { Terancam Gagal } \\
\text { Napas }\end{array}$ & - & 0 \\
\hline Total & $\mathbf{5 1}$ & $\mathbf{1 0 0 \%}$ \\
\hline
\end{tabular}

Tabel 4. Hubungan derajat merokok dengan derajat eksaserbasi asma pada pasien asma perokok aktif di Bangsal Paru RSUP Dr. M. Djamil Padang pada tahun 2007 sampai 2010

\begin{tabular}{|c|c|c|c|c|c|c|c|c|}
\hline \multirow{2}{*}{$\begin{array}{c}\text { Derajat } \\
\text { Merokok }\end{array}$} & \multicolumn{6}{|c|}{ Derajat Eksaserbasi Asma } & \multirow{2}{*}{$\mathrm{Jmh}$} & \multirow{2}{*}{$\%$} \\
\hline & Ringan & $\%$ & Sedang & $\%$ & Berat & $\%$ & & \\
\hline Ringan & 1 & 5,9 & 14 & 82,3 & 2 & 11,8 & 17 & 100 \\
\hline Sedang & 1 & 4,8 & 16 & 76,2 & 4 & 19,0 & 21 & 100 \\
\hline Berat & - & 0 & 9 & 75,0 & 3 & 25,0 & 12 & 100 \\
\hline Total & 2 & 3,9 & 39 & 76,5 & 9 & 17,6 & 50 & 100 \\
\hline
\end{tabular}

\section{UCAPAN TERIMA KASIH}

Ucapan terima kasih yang sedalam-dalamnya kepada Bapak dr.Oea Khairsyaf,Sp.P(K) dan Bapak Drs.Julizar,Apt.,M.Kes atas bimbingan, arahan dan motivasi dalam penelitian ini.

\section{DAFTAR PUSTAKA}

1. Global Initiative for Asthma (GINA). Global strategy for ashtma management and prevention. Updated 2011. Cape Town: University of Cape Town Lung Institute; 2011.

2. Centers for Disease Control and Prevention (CDC). Vital signs: asthma prevalence, disease characteristic, and self-management education -United States, 2001 - 2009. Morbidity and Mortality Weekly Report. 2011; 60(17): 547-52.

3. Depkes RI. Riset kesehatan dasar. RISKESDAS 2007. Jakarta: Departemen Kesehatan, Republik Indonesia; 2008. Perhimpunan Dokter Paru Indonesia (PDPI). Asma. Pedoman diagnosis \& penatalaksanaan di Indonesia (diunduh 9 Desember 2011). Tersedia dari: URL: HYPERLINK http://www.klikpdpi.com/konsensus/asma/asma.ht ml\#BABIV

4. Imelda S, Faisal Y, Wiwien HW. Hubungan derajat asma dengan kualitas hidup yang dinilai dengan asthma quality of life questionnaire. Majalah Kedokteran Indonesia. 2007; 57(12): 43545 . 
5. Yulinda E. Faktor pencetus serangan asma pada penderita asma yang berobat di poliklinik paru RS. DR. M. Djamil Padang (skripsi). Padang: Universitas Andalas; 2007.

6. National Heart, Lung, and Blood Institute (NHLBI). National asthma education and prevention program. Expert panel report 3: Guidelines for the diagnosis and management of asthma. Full report 2007. United States: U.S. Department of Health and Human Services; 2007.

7. Action on Smoking and Health (ASH). ASH research report: asthma and smoking. London: ASH; 2007.

8. Siroux V, Pin I, Oryszczyn MP, Moual NL, Kauffmann F. Relationships of active smoking to asthma and asthma severity in the EGEA study. Eur Resp Jour. 2000; 15: 470-77.

9. Thomson NC, Chaudhuri R, Livingston E. Asthma and cigarette smoking. Eur Resp Jour. 2004; 24 : 822-33.

10. Kemenkes RI. Riset kesehatan dasar. RISKESDAS 2010. Jakarta: Kementrian Kesehatan RI; 2010.

11. World Health Organization (WHO). WHO report on the global tobacco epidemic, 2008: the MPOWER package. Geneva: World Health Organization; 2008.

12. Perhimpunan Dokter Paru Indonesia (PDPI), 2003. Penyakit Paru Obstruktif Kronik (PPOK). Pedoman Diagnosis \& Penatalaksanaan di Indonesia (diunduh 5 Februari 2012). Tersedia dari: URL: HYPERLINK www.klikpdpi.com/konsensus/konsensusppok/ppok.pdf

13. Kusaka Y, Iki M, Kumagai S, Goto S. Decreased ventilatory function in hard metal workers. Occupational and Environmental Medicine. 1996; 53:194-9.

14. Watanabe $N$, Fukushima $M$, Taniguchi $A$, Okumura $\mathrm{T}$, Nomura $\mathrm{Y}$, Nishimura $\mathrm{F}$, et al. Smoking, white blood cell counts, and TNF system activity in Japanese male subjects with normal glucose tolerance. Tobacco Induced Diseases. 2011; 9:12.

15. Dahlan S. Statistik untuk kedokteran dan kesehatan. Edisi ke- 5. Jakarta: Salemba Medika; 2008.

16. Boulet LP, Deschesnes $F$, Chaboillez $S$, Lemière C. Protocol: influence of budesonide and budesonide/ formoterol on asthma control in smoking asthmatic adults. The Open Respiratory Medicine Journal. 2010; 4: 51-7.

17. Chaudhuri R, Livingston $E$, McMahon AD, Lafferty J, Fraser L, Spears M, et al. Effects of smoking cessation on lung function and airway inflammation in smokers with asthma. Am J Respir Crit Care Med. 2006; 174: 127-33.

18. Stapleton $M$, Thompson $A H$, George $C$, Hoover RM, Self TH. Smoking and asthma. J Am Board Fam Med. 2011; 24: 313-22.

19. Thomson NC, Chaudhuri R, Livingston E. Asthma and cigarette smoking. Eur Resp Jour. 2004; 24: 822-33.

20. Suharmiati, Handajani L, Handajani A. Hubungan pola penggunaan rokok dengan tingkat kejadian penyakit asma. Buletin Penelitian Sistem Kesehatan. 2010; 13(4): 394-403.
21. Eisner MD, Yelin EH, Trupin L, Blanc PD. Asthma and smoking status in a population-based study of California adults. Public Health Reports. 2001; 116: 148-57.

22. Montana Department of Public Health and Human Services. Asthma and smoking in Montana. Asthma surveillance report. April-June 2011. Montana: Department of Public Health and Human Services; 2011.

23. Jang AS, Park SW, Kim DJ, Uh ST, Kim YH, Whang $\mathrm{HG}$, et al. Effects of smoking cessation on airflow obstruction and quality of life in asthmatic smokers. Allergy Asthma Immunol Res. 2010; 2(4): 254-9.

24. Jindal SK, Gupta D. The relationship between tobacco smoke \& bronchial asthma. Indian J Med Res. 2004; 120: 443-53.

25. Cunha BA. Community-acquired pneumonia (diunduh 10 Desember 2012). Tersedia dari: URL: HYPERLINK http://emedicine.medscape.com/article/234240overview

26. National Institute for Health and Clinical Excellence (NICE). Tuberculosis. Clinical diagnosis and management of tuberculosis, and measures for its prevention and control. London: National Collaborating Centre for Chronic Conditions and the Centre for Clinical Practice; 2011.

27. Wenzel RP, Fowler AA. Acute bronchitis. The New England Journal of Medicine. 2006; 355 : 2125-30. 